\title{
HUBUNGAN KEPEMIMPINAN DENGAN SEMANGAT KERJA KARYAWAN PADA CV. PRIMA JAYA MOTOR DI TULANG BAWANG BARAT
}

\author{
Husna Purnama ${ }^{(1)}$, Wahyu Darmawan Syah ${ }^{(2)}$ \\ Fakultas Ekonomi Universitas Sang Bumi Ruwa Jurai \\ wahyudarmawan00@gmail.com,husna.purnama@fe.saburai.ac.id
}

\begin{abstract}
Abstrak. Pemimpin yang berhasil adalah pemimpin yang mampu berkomunikasi dan membangkitkan semangat kerja karyawan, sehinggga karyawan dengan senang hati dan penuh gairah menjalankan tugas tanpa adanya unsur paksaan. Pemimpin CV. Prima Jaya Motor menganut gaya kepemimpinan Birokrasi. Gaya birokrasi akan efektif bila semua karyawan mentaati atau mengikuti semua prosedur yang telah ditetapkan perusahaan, tetapi dalam permasalah gaya kepemimpinan ini karyawan kurang adanya ruang inovasi untuk menunjukan kemampuan karyawan dan karyawan kurang adanya perhatian khusus, sehingga membuat karyawan sering melanggar apa yang sudah ditetapkan perusahaan. Objek penelitian ini adalah Karyawan CV. Prima Jaya Motor perusahaan yang bergerak environment Engineering dan management consultant yang berada di Jalan Jendral Sudirman no.4 Daya Murni Tumijajar Kabupaten Tulang Bawang Barat. Adapun tujuan dari penelitian ini adalah untuk mengetahui hubungan kepemimpinan dengan semangat kerja karyawan pada Cv. Prima Jaya Motor Tulang Bawang Barat. Jumlah sampel yang akan penulis gunakan pada karyawan CV. Prima Jaya Motor di Tulang Bawang Barat 63 x 100\% $=63$ sampel. Berdasarkan nilai $t$ diketahui nilai thitung sebesar $2.835>t_{\text {tabel }} 2.000$, sehingga dapat disimpulkan bahwa variabel Kepemimpinan (X) Berhubungan Terhadap Variabel Semangat Kerja (y).
\end{abstract}

Kata kunci: Kepemimpinan, Karyawan, Motivasi, Semangat.

\section{PENDAHULUAN}

Dalam suatu organisasi agar dapat berperan untuk mencapai tujuannya adalah Semangat kerja. Semangat kerja yang tinggi merupakan hal yang penting dalam mewujudkan aparatur yang bersih dan berwibawa, terbukti bahwa hasil kerja yang baik dari para keryawan sangat besar manfaatnya bagi karyawan itu sendiri dan bagi perusahaan. Semangat kerja yang terbina dengan baik akan mendorong karyawan untuk melibatkan diri secara mendalam bekerja atau selalu mencurahkan segala usaha maupun kemampuannya untuk mencapai tujuan bersama.
Dengan adanya Semangat Kerja yang baik maka Produktivitas, efisien kerja dan integritas perusahaan dapat terjaga. Organisasi perusahaan adalah suatu sistem yang bergerak dalam mencari keuntungan, organisasi perusahaan terdiri dari satuan kerja yang besar, dirincian dalam satuan kerja yang lebih kecil (merupakan bagian) yang rinci dari satuan kerja yang lebih kecil lagi (merupakan sub bagian) dan seterusnya sampai bagian yang kecil.

Organisasi perusahaan melibatkan beberapa orang dan saling berinteraksi. Interaksi tersebut disusun dalam sebuah struktur yang dapat membantu dalam usaha mencapai tujuan bersama. Agar pelaksanaan kerja dalam organisasi 
perusahaan dapat terlaksana maka selain sekumpulan tenaga kerja juga dilibatkan perlengkapan, mesin - mesin, metode kerja, waktu, bahan baku yang umumnya berdaya guna dengan demikian perlu adanya manajemen.

Manajemen adalah faktor
kemanusian, mengikat suatu kelompok bersama dan memberi motivasi untuk mencapai tujuan yang telah ditetapkan organisasi perusahaan. Kepemimpinan merupakan salah satu faktor yang menunjang tercapainya tujuan organisasi (perusahaan), sehingga peran seorang pemimpin sangat penting dalam mengelola perusahaan.

Menurut peneliti, Pemimpin CV. Prima Jaya Motor menganut gaya kepemimpinan Birokrasi. Gaya birokrasi akan efektif bila semua karyawan mentaati atau mengikuti semua prosedur yang telah ditetapkan perusahaan, tetapi dalam permasalah gaya kepemimpinan ini karyawan kurang adanya ruang inovasi untuk menunjukan kemampuan karyawan dan karyawan kurang adanya perhatian khusus, sehingga membuat karyawan sering melanggar apa yang sudah ditetapkan perusahaan.

Pemimpin yang berhasil adalah pemimpin yang mampu berkomunikasi dan membangkitkan semangat kerja karyawan, sehinggga karyawan dengan senang hati dan penuh gairah menjalankan tugas tanpa adanya unsur paksaan, karena sebagai manusia, karyawan membutuhkan pengakuan bahwa dirinya mempunyai arti sendiri bagi perusahaan tempat mereka bekerja. Sebagai anggota kelompok merekapun butuh penghargaan atas partisipasi serta tenaga dan pikiran yang telah mereka curahkan bagi kepemimpinan kelompok. Oleh karenanya setiap perusahaan haruslah dapat menjaga semangat kerja karyawannya dengan jalan memberikan perhatian dan kebutuhan karyawan tersebut. Hubungan kepemimpinan dengan semangat kerja pada CV. Prima Jaya Motor sangatlah diperlukan karena dengan hubungan yang baik akan meningkatkan semangat kerja yang tinggi hal ini dapat dilihat dalam berbagai wujud yaitu dengan rasa senang dan puas, tidak merasa jemu, waktu habis tidak terasa,saling membantu dalam memenuhi pelayanan konsumen. Indikator kompensasi finansial juga mempengaruhi semangat kerja karyawan karena kompensasi finansial merupakan pendapatan yang berbentuk uang yang diterima karyawan sebagai imbalan atau jasa yang diberikan oleh perusahaan. Dari uraian diatas maka penulis mengambil judul

\section{: "Hubungan Kepemimpinan Dengan Sem'angat Kerja Karyawan Pada CV. Prima Jaya Motor Di Tulang Bawang Barat."}

\section{KAJIAN TEORI}

\section{Pengertian Kepemimpinan}

Dalam suatu organisasi dibutuhkan adanya keteraturan dimana keteraturan tersebut dapat dilaksanakan apabila didalamnya terdapat orang yang dapat mengatur dan menciptakan suasana yang memungkinkan adanya suatu kegairahan kerja. Adanya seorang pemimpin dianggap seorang ciri suatu organisasi. Istilah kepemimpinan berasal dari kata "pimpin" yang artinya bimbing atau tuntun dari kata pimpin lahirlah kata kerja "memimpin" yang artinya membina atau menuntun dan kata benda "pemimpin" yaitu orang yang berfungsi memimpin,atau orang yang membimbing atau menuntun.

Banyak teori bagaimana fungsi seseorang pemimpin dalam organisasi dan dapat dimengerti bahwa adalah tokoh penuntun dalam sautu organisasi yang lebih mampu dari orang - orang dalam kelompoknya dan karenanyalah maka 
seorang pemimpin diharapkan dapat menjadi motor penggerak dari organisasi yang dia pimpin untuk mencapai tujuan yang ditetapkan bersama. Kepemimpinan merupakan suatu proses pemberian pengaruh antara seorang pemimpin dengan orang yang di pimpinnya.

Kepemimpinan merupakan hal yang penting bagi organisasi pendapat dari, Wahjosumidjo (2003), sebagai berikut :

"Kepemimpinan adalah kemampuan yang ada pada diri seorang leader yang berupa sifat - sifat tertentu". Demikian pentingnya peranan kepemimpinan dalam upaya pencapaian tujuan organisasi, sehingga dapat dikatakan bahwa sukses atau gagal yang dialami organisasi tersebut sebagian besar ditentukan oleh kualitas kepemimpinan yang dimiliki seseorang diserahi tugas untuk memimpin organisasi. Untuk lebih jelasnya, maka dibawah ini akan dijelaskan beberapa pengertian mengenai kepemimpinan menurut para ahli menurut Siagian (2005), adalah :

1. Sebagai pusat proses kelompok.

2. Suatu ungkapan kepribadian dan efeknya terhadap orang lain.

3. Seni yang cukup dapat mempengaruhi orang lain.

4. Menjalankan pengaruh.

5. Satu tindakan tingkah laku.

6. Satu bentuk persuasi satu kekuatan hubungan.

7. Satu efek interaksi.

8. Satu peran yang diatur berlainan satu sama lain.

\section{Syarat - Syarat Kepemimpinan}

Menurut Kartini Kartono (2008) Untuk menajalankan kegiatan kepemimpinan diperlukan syarat - syarat tertentu sehingga kepemimpinan itu dapat berhasil dengan baik adapun dibawah ini adalah syarat - syarat tersebut

1. Kekuasaan, yaitu kekuasaan otoritas dan legalitas yang memberikan wewenang kepada pemimpin untuk mempengaruhi orang lain untuk menggerakan sesuatu.

2. Kewibawaan, yaitu kelebihan, keunggulan, keutamaan sehingga orang mampu membawahi, mengatur orang lain, agar orang tersebut patuh pada pimpinan dan bersedia melakukan perbuatan - perbuatan tertentu.

3. Kemampuan, segala daya, kesanggupan, kekuatan dan kecakapan serta keterampilan, teknis maupun sosial yang dianggap melebihi kemapuan anggota biasa.

\section{Pengertian Semangat Kerja}

Semangat kerja adalah sikap mental dari individu atau kelompok menunjukan kegairahan untuk melaksanakan pekerjaannya sehingga mendorong untuk mampu bekerja sama dan dapat menyelesaikan tugas tepat pada waktunya dengan rasa tanggung jawab terhadap pekerjaan yang dibebankan kepadanya. Untuk membahas tentang semangat kerja maka ada banyak para ahli memberikan definisi semangat kerja dari sudut pandang yang berbeda.

Menurut Hasibuan (2010:152 ), Semangat kerja adalah keinginan dan kesungguhan seseorang mengerjakan dengan baik serta berdisiplin untuk mencapai prestasi kerja yang maksimal.

Menurut Tohardi (2002:427), semangat kerja adalah kemampuan sekelompok orang - orang untuk bekerja sam dengan giat dan konsukuen dalam mengejar tujuan bersama.

\section{Faktor - Faktor Yang Mempengaruhi Semangat Kerja}

Untuk dapat meningkatkan semangat kerja karyawan maka perusahaan harus menciptakan kondisi kerja yang dapat mendorong semangat kerja. Adapun faktor 
- faktor yang mempengaruhi semangat kerjakaryawan tersebut menurut Mathis (2001:98) yaitu:

a. Kompensasi.

b. Pendidikan dan pelatihan.

c. Promosi jabatan.

d. Lingkungan kerja.

\section{METODE PENELITIAN}

\section{Objek Penelitian}

Yang menjadi objek penelitian ini adalah Karyawan CV. Prima Jaya Motor perusahaan yang bergerak environment Engineering dan management consultant yang berada di Jalan Jendral Sudirman no.4 Daya Murni Tumijajar Kabupaten Tulang Bawang Barat, penelitian ini dilakukan dari bulan Mei sampai dengan Agustus 2019.

\section{Metode dan Teknik Pengumpulan Data}

Dalam penelitian ini metode pengumpulan data yang digunakan adalah:

a. Data primer merupakan data yang diperoleh langsung tanpa perantara orang lain sebagai pihak ketiga, data primer ini diperoleh dengan wawancara melalui responden.

b. Data sekunder merupakan data yang diperoleh melalui orang lain yang berhubungan dengan permasalahan yang dipecahkan. Data sekunder ini diperoleh melalui cara studi dokumenter yaitu mengumpulkan dan mempelajari berkas atau dokumen kantor.

\section{Sampel dan Populasi}

Menurut Suharsimi Arikunto (2011), apabila objek penelitian kurang dari 100 maka lebih baik mengambil semua, selanjutnya jika jumlah lebih dari 100 maka dapat diambil antara $10-15 \%$. Jadi yang menjadi sampel dalam penelitian ini adalah semua karyawan CV. Prima Jaya Motor. Sehingga jumlah sampel yang akan penulis gunakan pada karyawan CV. Prima Jaya Motor di Tulang Bawang Barat 63 x 100\% $=63$ sampel.

\section{Metode Analisis Data}

\section{Analisis Kualitatif}

Analisa kualitatif digunakan sebagai metode untuk menganalisa permasalahan berdasarkan konsep dan teori manajemen sumber daya manusia. Dalam metode ini juga menganalisa masalah dengan teoriteori yang berkaitan dengan masalah kepemimpinan dan semangat kerja.

Analisis kualitatif dilakukan dengan analisis tabel tunggal atau secara parsial yang menggambarkan kriteria masingmasing variabel independen, dalam penelitian ini yaitu variabel kepemimpinan (X) dan variabel dependen yaitu semangat kerja (Y). termasuk kedalam kriteria masing-masing variabel penelitian tersebut sesuai dengan jawaban yang ada pada pengukuran variabel diatas. penelitian ini dengan menggunakan aplikasi program computer SPSS Versi 20

\section{Regresi Linear Sederhana}

Regresi Linear Sederhana adalah hubungan secara linear antara satu variabel independen $(\mathrm{X})$ dengan variabel dependen (Y). Analisis ini bertujuan untuk mengetahui arah hubungan antara variabel independen dengan variabel dependen apakah positif atau negative dan untuk memprediksi nilai dari variabel dependen apabila nilai independen mengalami kenaikan atau penurunan. Data yang digunakan biasanya berskala interval atau rasio.

Rumus :

$$
Y=a+b X
$$


Keterangan :

$\mathrm{Y}=$ Variabel Dependen

$\mathrm{X}=$ Variabel Independen

$\mathrm{a}=$ Konstanta

$b=$ Koefisien Regresi

\section{Uji Asumsi Klasik}

Uji Asumsi klasik adalah persyaratan statistik yang harus dipenuhi pada analisis regresi linear sederhana. Pengujian asumsi klasik adalah suatu pengujian yang bertujuan untuk mengetahui apakah model regresi yang digunakan bebas dari kesalahan pengganggu yang dapat hasil penelitian tersebut. Adapun uji asumsi klasik yang dipakai dalam penelitian ini adalah uji normalitas dan uji linearitas.

\section{Uji Hipotesis / Uji signifikansi Simultan ( Uji F )}

Uji $F$ pada dasarnya menunjukkan apakah semua variabel independen atau bebas yang dimasukkan dalam model mempunyai pengaruh secara bersama-sama terhadap variabel dependen atau terikat Ghozali (2013). Uji-F pada dasarnya menunjukkan semua variabel independen yang dimasukkan dalam model ini mempunyai pengaruh secara bersamasama terhadap variabel dependen. Dengan tingkat signifikansi 0,05 (5\%), maka kriteria pengujian adalah sebagai berikut:

1. Bila nilai signifikansi $<0,05$, maka H0 diterima, artinya terdapat pengaruh yang signifikan antara semua variabel independen terhadap variabel dependen.

2. Bila nilai signifikansi $>0,05$, maka H0 ditolak, artinya semua variabel independen tidak berpengaruh terhadap variabel dependen.

\section{HASIL DAN PEMBAHASAN}

\section{Uji Validitas}

Menurut Bawono (2006:68), sebuah data yang didapat dari kuesioner, sebaiknya diuji validitas. Uji validitas dilakukan untuk mengungkapkan apakah pernyataan pada kuesiner tersebut sahih atau tidak. Berikut adalah hasil uji validitas yang dilakukan :

Table Uji Validitas

\begin{tabular}{|l|l|l|l|}
\hline $\begin{array}{l}\text { Pernyataan } \\
\text { Kepemimpinan }\end{array}$ & r hitung & r tabel & $\begin{array}{l}\text { Keteran } \\
\text { gan }\end{array}$ \\
\hline 1 & 0,238 & 0,209 & Valid \\
\hline 2 & 0,506 & 0,209 & Valid \\
\hline 3 & 0,490 & 0,209 & Valid \\
\hline 4 & 0,493 & 0,209 & Valid \\
\hline 5 & 0,575 & 0,209 & Valid \\
\hline 6 & 0,596 & 0,209 & Valid \\
\hline 7 & 0,328 & 0,209 & Valid \\
\hline 8 & 0,560 & 0,209 & Valid \\
\hline 9 & 0,630 & 0,209 & Valid \\
\hline 10 & 0,332 & 0,209 & Valid \\
\hline Semangat Kerja & & & \\
\hline 1 & 0,378 & 0,209 & Valid \\
\hline 2 & 0,419 & 0,209 & Valid \\
\hline 3 & 0,585 & 0,209 & Valid \\
\hline 4 & 0,737 & 0,209 & Valid \\
\hline 5 & 0,503 & 0,209 & Valid \\
\hline 6 & 0,530 & 0,209 & Valid \\
\hline 7 & 0,621 & 0,209 & Valid \\
\hline 8 & 0,305 & 0,209 & Valid \\
\hline 9 & 0,303 & 0,209 & Valid \\
\hline 10 & 0,209 & Valid \\
\hline Sumber Data Primer yang & & & \\
\hline & & &
\end{tabular}

Sumber : Data Primer yang diolah, 2019

Berdasarka hasil uji validitas, pertanyaan Kepemimpinan sebanyak 10 pertanyaan, setelah dilakukan uji validitas semua pertanyaan valid itu berarti pernyataan sesuai dengan responden yang mengisinya. Sedangkan pertanyaan 
Semangat Kerja sebanyak 10 pertanyaan semuanya dinyatakan valid.

\section{Uji Reliabilitas}

Uji reliabilitas pada penelitian ini menggunakan Cronbach Alpha statistic ini berguna untu mengetahui apakah pengukuran reliable. Suatu variabel dikatakan reliable jika nilai Cronbach Alpha > 0,6. Adapun hasil uji reliabilitas yang diperoleh dalam penelitian ini adalah sebagai berikut :

Tabel Uji Reliabilitas

\begin{tabular}{|l|l|l|l|}
\hline Variabel & $\begin{array}{l}\text { Cronbach } \\
\text { Alpha }\end{array}$ & Kritis & Keterangan \\
\hline $\begin{array}{l}\text { Kepemimpin } \\
\text { an }\end{array}$ & 0,633 & 0,6 & Reliabel \\
\hline $\begin{array}{l}\text { Semangat } \\
\text { Kerja }\end{array}$ & 0,698 & 0,6 & Reliabel \\
\hline
\end{tabular}

Sumber : Data Primer yang dio\$lah, 2019

Berdasarkan keterangan tabel dijelaskan bahwa variabel kepemimpinan maupun semangat kerja karyawan semuanya reliable yaitu nilai alpha nya lebih besar dari pada nilai kritisnya.

\section{Regresi Linier Sederhana}

Uji regresi digunakan untuk mengetahui apakah variabel Kepemimpinan berpengaruh secara signifikan terhadap variabel Semangat Kerja pada Cv. Prima Jaya Motor. Dalam penelitian ini peneliti menggunakan bantuan SPSS versi 20.

Tabel Persamaan Regresi Linier Sederhana

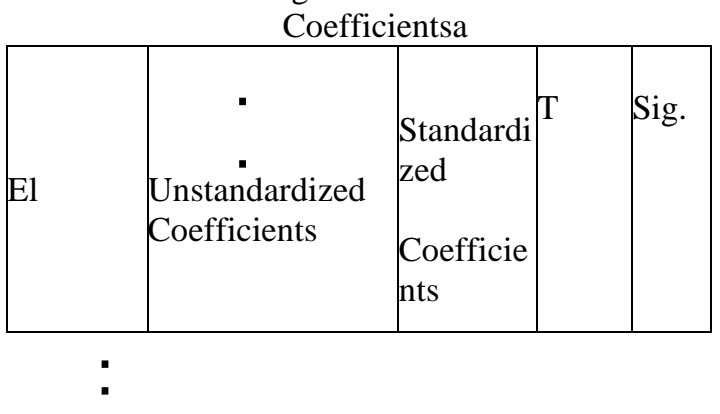

\begin{tabular}{|l|l|l|l|l|l|}
\hline & B & Std. Error & Beta & & \\
\hline Constant & 34.249 & 4.367 & & 7.843 & .000 \\
\hline $\begin{array}{l}\text { Kepemim } \\
\text { pinan }\end{array}$ & .276 & .097 & .341 & 2.835 & .006 \\
\hline
\end{tabular}

ependent Variable: semangat kerja

Berdasarkan Tabel diketahui nilai signifikansi di peroleh nilai signifikansi sebesar $0,0006<0,05$, sehingga dapat disimpulkan bahwa variabel Kepemimpinan (X) berhubungan terhadapat variabel Semangat Kerja (Y).

Berdasarkan nilai $\mathrm{t}$ : diketahu nilai thitung sebesar $2.835>$ ttabel 2.000, sehingga dapat disimpulkan bahwa variabel Kepemimpinan (X) Berhubungan Terhadap Variabel Semangat Kerja (y).

\section{Uji F}

Uji $F$ dilakukan untuk melihat kemaknaan dari hasil model regresi tersebut. Bila nilai Fhitung > Ftabel atau tingkat signifikannya $<5 \%(\alpha=5 \%=0,05)$ maka hal ini menunjukkan bahwa Ho ditolak dan Ha diterima yang berarti bahwa terdapat pengaruh yang signifikan antara variabel bebas Semangat Kerja terhadap Variabel terikat Kepemimpinan secara simultan.

Tabel Hasil Uji Statistik F (annova $\left.{ }^{2}\right)$
\begin{tabular}{|l|l|l|l|l|l|}
\hline Model & $\begin{array}{l}\text { Sum of } \\
\text { squares }\end{array}$ & $\begin{array}{l}\text { Df } \\
\text { square }\end{array}$ & $\mathrm{F}$ & Sig. \\
\hline $\begin{array}{l}\text { Regressi } \\
\text { on }\end{array}$ & 42.510 & 1 & 42.510 & 8.039 & $\begin{array}{l}.006 \\
\mathrm{~b}\end{array}$ \\
\hline Residual & 322.569 & 61 & 5.288 & & \\
\hline Total & 365.079 & 62 & & & \\
\hline
\end{tabular}

a. Dependent Variable: semangat kerja

b. Predictors: (Constant), kepemimpinan

dari tabel hasil uji anova diatas diketahui bahwa nilai Fhitung pada tabel 
diatas sebesar 8,039 sedangkan nilai Ftabel untuk penelitian ini adalah sebesar 4,00 maka Ha diterima artinya Fhitung > Ftabel atau nilai 8,039>4,00 sedangkan nilai probabilitas pada tabel diatas sebesar 0,006 maka Ho diterima artinya probabilitas lebih kecil daripada 0,05 atau $0,006<0,05$. Model penelitian ini baik atau layak untuk digunakan sehingga penelitian ini dapat diteruskan.

\section{KESIMPULAN DAN SARAN}

\section{Kesimpulan}

Penelitian ini bertujuan untuk mengkaji dan menganalisis pengaruh kepemimpinan terhadap semangat kerja karyawan di CV. Primajaya Motor Tulang Bawang Barat. Data dalam penelitian menggunakan data primer yang diperoleh langsung dari CV. Prima Jaya Motor. Sampel dalam penelitian ini adalah karyawan Cv. Prima Jaya motor yang diambil dengan kuesioner. Dengan mengajukan pertanyaan sebanyak 20 pernyataan dengan keseluruhan kuesioner penelitian sebanyak 63 karyawan. Penelitian ini sepanjang periode Mei sampai dengan Agustus 2019. Analisis ini dilakukan dengan menggunakan analisis regresi linear sederhana dengan tingkat kepercayaan 95\%. Data diolah dengan menggunakan program SPSS versi 20. Berdasarkan hasil pengolahan data dan pengujian serta hipotesis yang mengacu pada masalah dan tujuan penelitian, maka dapat dirumuskan kesimpulan bahwa : Kepemimpinan sangat berpengaruh signifikan terhadap semangat kerja karyawan. Oleh karena itu perlu mengetahui semangat kerja perlu dipertahankan

\section{Saran}

Berdasarkan pembahasan yang dilakukan oleh penulis maka terdapat beberapa saran yang dapat diperhatikan sebagai bahan masukan pada $\mathrm{Cv}$. Prima Jaya Motor Tulang Bawang Barat mengenai kepemimpinan dan semangat kerja karyawan diantaranya :

1. Pemimpin memberikan konsekuensi pekerjaan yang sesuai agar karyawan merasa puas. Lebih mempertegas sanksi yang diberikan karyawan agar karyawan bekerja lebih sungguh sungguh. Lebih memperjelas teguran dan solusi dalam pekerjaan kepada karyawan agar karyawan lebih mudah untuk memahami. Pemimpin memiliki tindakan antisipasi sebelum terjadinya masalah.

2. Karyawan harus mempersiapkan tugas yang akan dikerjakannya lebih baik, memiliki tuntutan keberhasilan yang tinggi, memenuhi setiap target kerjanya, lebih giat mencari solusi terbaik dalam masalah pekerjaan, dan memiliki ambisi yang tinggi untuk mencapai posisi atau jabatan yang lebih baik dari sebelumnya.

3. Besarnya pengaruh kepemimpinan terhadap semangat kerja karyawan berdasarkan penelitian ini, dapat dijadikan pertimbangan bagi perusahaan dalam usaha untuk meningkatkan semangat kerja karyawan sehingga perusahaan dapat melaksanakan kegiatan usahanya dengan baik dan mewujudkan visi dan misi secara efektif dan efisien.

\section{DAFTAR PUSTAKA}

Arikunto, Suharsimi.2011. Produser Penelitian. Jakarta:Renika Cipta.

Asmadewira. 2016. Hubungan Kepemimpinan Dengan Semangat 
Kerja Karyawan Pada Jasa Perhotelan (Kasus Hotel Benteng Pekanbaru). Indonesia: Fakultas Ilmu Sosial Dan Ilmu Politik. Universitas Riau.

Bawono, Anton. 2006. Multivariate Analysis Dengan SPSS. Salatiga: STAIN Salatiga Press.

Ghozali, Imam H. 2005. Analisis Multivariate Dengan Program SPSS.Semarang:Universitas

Diponegoro.

Ghozali, Imam. 2013. Aplikasi Analisis Multivariat Dengan Program IBM SPSS. Edisi 7.Semarang: Penerbit Universitas Dipeonegoro.

Handoko, T. Hani. 2010. Manajemen Personalia dan Manajemen Sumber Daya Manusia. Yogyakarta: BPFEYogyakarta.

Hasibuan, Sp. 2010. Manajemen Sumber Daya Manusia. Jakarta: Bumi Aksara. 